\title{
POLEMIKA O STRÁŽCI ÚSTAVY V KONTEXTU SOUČASNÝCH DEBAT O DĚLBĚ MOCI
}

\author{
PAVEL ONDŘEJEK*
}

\begin{abstract}
Dispute over the guardian of the constitution in the context of current debates about the separation of powers

A defence of the institution of constitutional judiciary appears as an important part throughout the works of Hans Kelsen. A model of constitutional review which won recognition in the constitutions of Czechoslovakia and Austria in the 1920th was clearly inspired by that author. A question of how to overcome a tension between a legislator and constitutional courts remains very topical at present times as well. The article outlines a dispute over the guardian of the constitution between two remarkable lawyers of the pre-World War II. period - Hans Kelsen and Carl Schmitt. Finally, the article expounds current discourse dealing with the question of position and role of constitutional courts. In the article, the author argues for judicial minimalism and passivist decision-making.
\end{abstract}

Keywords: guardian of the constitution, constitutional review, constitutional courts, legislator, decisional minimalism, judicial passivism

Klíčová slova: strážce ústavy, ústavní přezkum, ústavní soudy, zákonodárce, minimalismus v soudním rozhodování, soudcovský pasivismus

DOI: $10.14712 / 23366478.2017 .24$

Tvrzení, že Hans Kelsen je géniem, jehož myšlenky jsou inspirativní i na počátku 21. století, není přehnané. ${ }^{1}$ Je však také pravdou, že ryzí nauka právní, jejímž byl hlavním představitelem, již v současné právní filozofii rozvíjena není. Současný pohled na právo je poznamenán jednak návratem některých autorů k prrirozenoprávním doktrínám po druhé světové válce, zejména $\mathrm{k}$ univerzalitě lidských práv, a dále rozmachem právně sociologických směrů ovlivňujících i právní pozitivismus. ${ }^{2}$ Kelsen svými úvahami, nap̌r. o demokracii nebo podmínkách platnosti pozitivního práva, ovlivnil a stále ovlivňuje řadu autorů, a to nejen právních pozitivistů.

* Odborný asistent na katedře teorie práva a právních učení Právnické fakulty UK v Praze. Příspěvek vznikl v rámci programu Progres Q04 s názvem Právo v měnícím se světě. Za připomínky děkuji Janě Ondřejkové, která téma role soudů zpracovává v připravované monografii s názvem Vnější limity soudcovské interpretace a argumentace. Praha: Leges, v tisku.

1 KRAWIETZ, Werner: Hans Kelsen - Ein normativer Mastermind des Rechts und der Rechtstheorie für das 21. Jahrhundert. Rechtstheorie, sv. 38, 2007, s. 33-98.

2 Srov. nedávnou polemiku reflektující trvalý spor iuspozitivismu a non-pozitivismu: PŘIBÁŇ, Jiří: Lesk a bída právního pozitivismu. In PR̆IBÁŇ, Jiří - HOLLÄNDER, Pavel a kol.: Právo a dobro v ústavni demokracii. Polemické a kritické úvahy. Praha: Sociologické nakladatelství, 2011, s. 27-34. HOLLÄNDER, Pavel: Vážně jsme už všichni pozitivisté? In PŘIBÁŇ, Jiří - HOLLÄNDER, Pavel a kol.: Právo a dobro v ústavní demokracii. Polemické a kritické úvahy. Praha: Sociologické nakladatelství, 2011, s. 35-41. 
Jednu z významných stránek jeho díla představuje obhajoba instituce ústavního soudu, tedy modelu ústavního přezkumu, který se pod Kelsenovým vlivem prosadil ve dvacátých letech minulého století $\mathrm{v}$ ústavách Rakouska a rovněž Československa. V této své teorii Kelsen mimo jiné usiluje o překonání napětí mezi zákonodárnou a soudní mocí, ${ }^{3}$ což je otázka, která je i v dnešní době stále aktuální (nikoliv pouze v anglosaském prostředí, kde se popisuje jako protivětšinový problém - countermajoritarian difficulty). ${ }^{4}$

Druhou stránkou Kelsenovy teorie ústavního přezkumu je obhajoba ústavních soudů jakožto optimálních strážců ústavy, což je teze, kterou propracoval v polemice s německým právním filozofem Carlem Schmittem. Právě přiblížení této polemiky se budu věnovat $\mathrm{v}$ úvodu svého př́spěvku. $\mathrm{V}$ návaznosti na prezentaci Kelsenových myšlenek se pokusím zhodnotit, které z jeho argumentů obstojí v současných debatách o dialogu mezi zákonodárcem a ústavními soudy.

Již v úvodu je vhodné připomenout, že idea ústavního soudnictví, potažmo role ústavních soudů, se vyvíjí současně s rozvojem veřejného práva. ${ }^{5} \mathrm{~V}$ tomto př́spěvku budu vycházet $\mathrm{z}$ teze, že idea ústavního přezkumu vykazuje jednak určitou kontinuitu s myšlenkami, na nichž byl tento přezkum založen, na straně druhé však je rovněž poznamenán vývojem ústavního práva od poloviny minulého století. ${ }^{6}$

\section{POLEMIKA HANSE KELSENA S CARLEM SCHMITTEM O STRÁŽCI ÚSTAVY}

V roce 1928 vystoupil Hans Kelsen na sněmu Spolku německých státovědců (Vereinigung der Deutschen Staatsrechtslehrer) s obhajobou existence speciálního ústavního soudu, jehož pravomocí by bylo rušit zákony a jiné právní předpisy pro rozpor s ústavou. ${ }^{7}$ Modelem pro Německo měl samozřejmě být rakouský ústavní soud, jehož soudcem v té době Kelsen byl a jehož pomáhal jako spolutvưrce rakouské ústavy vytvářet. Komplexní zpracování argumentů přednesených na výše uvedeném fóru Kelsen sepsal ve stati o podstatě a vývoji ústavního soudnictví (Wesen und Entwicklung der Staatsgerichtsbarkeit), ${ }^{8}$ na kterou Schmitt reagoval spisem Strážce ústavy (Der Hüter

3 VINX, Lars: Hans Kelsen's Theory of Law. Legality and Legitimacy. Oxford: Oxford University Press, 2007, s. 145.

4 Poprvé byla tato teze komplexně představena v klasickém díle: BICKEL, Alexander: The Least Dangerous Branch. The Supreme Court at the Bar of Politics. 2. vyd., New Haven, London: Yale University Press, 1962.

5 K tématu proměn veřejného práva, kterému se není možné zde věnovat, odkazuji na jinou svou práci: ONDŘEJEK, Pavel: Proměny veřejného práva a jejich vliv na ochranu lidských práv. Jurisprudence, sv. 24 , č. $3 / 2015$, s. $30-35$.

6 Podobně M. Antoš uvádí, že „snaha vykládat dnešní postavení ústavních soudů prostřednictvím Kelsenových myšlenek představuje ... prrekážku správného př́istupu k doktrinárnímu zkoumání judikatury Ústavního soudu a omezuje rámec její kritické reflexe.“ ANTOŠ, Marek: Současné ústavní soudnictví. Nepravý dědic Hanse Kelsena? Jurisprudence, sv. 26, č. 2/2017, s. 36.

7 VINX, Lars: The Guardian of the Constitution. Hans Kelsen und Carl Schmitt on the Limits of Constitutional Law. Oxford: Oxford University Press, 2015, s. 7.

8 KELSEN, Hans: Wesen und Entwicklung der Staatsgerichtsbarkeit. Veröffentlichungen der Vereinigung der Deutschen Staatsrechtslehrer, č. 5/1929, s. 30-88. Opětovně publikováno v: KLECATSKY, Hans - 
der Verfassung) z roku $1931,{ }^{9}$ po němž následovala kritická Kelsenova recenze této knihy. ${ }^{10}$ Pro čtenáře jsou prrístupné anglické překlady těchto textů (v prrípadě Schmittovy knihy jejích hlavních kapitol) v monografii editované Larsem Vinxem. ${ }^{11}$

$\mathrm{K}$ vyvrcholení polemiky o strážci ústavy došlo pod vlivem konkrétní dějinné události: dekretu ř́řského prezidenta Hindenburga ze dne 20. ř́inna 1932 vydaného podle článku 48 Výmarské ústavy. Na základě dekretu byl kancléŕ von Papen zmocněn sám sestavit novou pruskou vládu, která nahradila stávající, vzešlou z voleb. Důvodem, podle všeho však zástupným, $\mathrm{k}$ vydání prezidentského dekretu byly nepokoje a střety mezi komunisty, nacisty a policií ve městě Altona. ${ }^{12}$ Článek 48 Výmarské ústavy umožňoval říšskému prezidentovi vydat dekret $\mathrm{k}$ obnovení veřejné bezpečnosti a pořádku v př́ípadě jejího závažného porušení nebo ohrožení. ${ }^{13}$

Pruská vláda napadla tento prezidentský dekret před Státním soudem (Staatgerichtshof), celkově však neuspěla. Státní soud rozhodl již 25. ř́ijna 1932, že Prusko sice neporušilo závazky k Říši, a proto říšská vláda nemůže převzít veškeré pravomoci pruské vlády trvale, nicméně opatření dekretu bylo odůvodněno ochranou veřejné bezpečnosti. ${ }^{14}$ Toto rozhodnutí Státního soudu (před nímž vystupoval jako zástupce říšské vlády Carl Schmitt a na straně Pruských sociálních demokratů neméně významný právník Hermann Heller) znovu oživilo debatu o úloze soudů a řišského prezidenta v německém ústavním systému. ${ }^{15}$

Pro bližší věcné seznámení se základními argumenty pro fungování ústavního soudnictví je však třeba připomenout východiska obecné Kelseny teorie, které se začaly systematičtěji v jeho díle projevovat zejména od 2. vydání jeho práce Hauptprobleme der Staatsrechtslehre v roce 1923. ${ }^{16}$ Nejvýznamnějš́ je jeho úsilí o vytvoření ryzí nauky právní, které ,se chce omezit pouze na poznání, vztahujicí se k právu, a vyloučit z okruhu tohoto poznání vše, co nepřináleži k onomu předmětu ... Ryzí nauka právní chce oprostit právní vědu od všech prvků, jež jsou cizí jejímu předmětu. To je její základní

\footnotetext{
MARCIC, René - SCHAMBECK, Herbert (eds.): Die Wiener rechttheoretische Schule. Schriften von Hans Kelsen, Adolf Merkl, Alfred Verdross. II. svazek, Wien: Verlag Österreich, 2010, s. 1485-1532 (z posléze uvedené republikace budu vycházet).

9 SCHMITT, Carl: Der Hüter der Verfassung. Berlin: Dunckler \& Humblot, 1931.

10 KELSEN, Hans: Wer soll der Hüter der Verfassung sein? Die Justiz, sv. 6, 1931, s. 576-628.

11 VINX, Lars: The Guardian of the Constitution. Hans Kelsen und Carl Schmitt on the Limits of Constitutional Law. Oxford: Oxford University Press, 2015. Níže budu citovat anglické překlady výše uvedených Schmittových a Kelsenových děl v uvedené monografii Larse Vinxe.

$12 \mathrm{~K}$ dobovému kontextu př́ípadu, včetně politických motivů jeho aktérů, viz např. DYZENHAUS, David: Legality and Legitimacy. Carl Schmitt, Hans Kelsen und Hermann Heller in Weimar. Oxford: Clarendon Press, 1997, s. 2 a násl. VINX, Lars: The Guardian of the Constitution... Op. cit., s. 1 a násl.

13 Čl. 48 odst. 2 Ústavy Německé říše (Výmarské ústavy) z 11. srpna 1919 zní: „V případě, že je narušována nebo ohrožena veřejná bezpečnost a pořádek, říšský prezident může na území celé Říše přijmout nutná opatření a přiměřeně zakročit pomocí ozbrojené moci.“ Citován český překlad v: VLČEK, Eduard - SCHELLE, Karel: Dokumenty ke studiu moderních dějin státu a práva. II. díl, Brno: Masarykova univerzita, 1994, s. 61.

14 VINX, Lars: The Guardian of the Constitution... Op. cit., s. 4.

15 Podrobněji k tomuto rozhodnutí srov. též DYZENHAUS, David: Legality and Legitimacy... Op. cit., s. 32-37.

16 PAULSON, Stanley L.: Introduction. In PAULSON, Stanley L. - LITSCHEWSKI PAULSON, Bonnie (eds.): Norms and Normativity. Critical Perspectives on Kelsenian Themes. Oxford: Clarendon Press, 1998, s. xxiv.
} 
metodologický princip. "17 Ponechme stranou v tuto chvíli debatu, nakolik se v samotném Kelsenově díle lze zcela obejít bez otázek fakticity. ${ }^{18}$

Druhým významným momentem je převzetí a rozpracování teorie o stupňovité výstavbě právního řádu, s níž původně přichází Kelsenův žák Adolf Merkl. Podle ní každá právní norma vzniká na základě zmocnění právní normy vyšší právní síly. ${ }^{19}$ Garance legality podle Kelsena neznamená pouze zajistit soulad jednotlivých rozhodnutí soudů a správních orgánů se zákony, nýbrž i soulad normativních právních aktů, zejména zákonů, s ústavou. ${ }^{20}$ Právě soudní a správní rozhodnutí jsou v pojetí zastánců normativní teorie individuální normy, které vznikají jako konkretizace norem obecných (zejména těch obsažených v zákoně). ${ }^{21}$ Hans Kelsen se předně staví kriticky k tomu, aby řešení na straně jedné právních a na straně druhé politických otázek bylo spojováno s konkrétními institucemi. Toto je hlavní argument Schmitta, proč by měl prezident, jako politický orgán, řešit výjimečné situace a nenechávat řešení na soudu, který k politickému řešení otázek nemá dostatek legitimity. Oproti vývoji v Evropě, kde právní regulace postupně proměňuje tradiční minimální stát, poukazuje Schmitt na americkou judikaturu Nejvyššího soudu z přelomu 19. a 20. století. ${ }^{22}$

Podle Kelsena nelze procesy tvorby a aplikace práva zcela odlišovat. I při rozhodovací činnosti soudů nebo správních orgánů jsme podle Kelsena svědky tvorby práva, kdy tyto orgány musejí řešit otázky explicitně v právu neupravené. ${ }^{23}$ Schmittova představa, že soudy pouze mechanicky aplikují právní normy dané zákonodárcem, podle Kelsena neobstojí.

Pokud jde o formu ochrany ústavnosti, za jediný skutečně efektivní nástroj Kelsen považuje zrušení jakéhokoliv aktu, který by se ústavě příčil. ${ }^{24}$ Toto zrušení však nevnímá jako zásah do zákonodárné moci, nýbrž jako výkon legislativní pravomoci, která je přenesena na soud. Soud se tedy stává negativním zákonodárcem, na rozdíl od parlamentu, který je zákonodárcem pozitivním. ${ }^{25} \mathrm{~K}$ odůvodnění soudního zásahu do

17 KELSEN, Hans: Ryzí nauka právní. Metoda a základní pojmy. (překl. V. Chytil). Brno - Praha: Orbis, 1933, s. 7.

18 Julius Stone například poukazuje na vymezení platnosti právního systému skrze efektivitu: „Přestože platnost a efektivita jsou dva zcela odlišné pojmy, existuje přesto mezi nimi velmi důležitý vztah. Norma je považována za platnou pouze za předpokladu, že náleží do systému norem, řádu, který je celkově efektivní. Tedy, efektivita je podmínka, nikoliv důvod platnosti. Norma není platná, protože je efektivní, je platná, pokud řád, ke kterému náleží, je celkově efektivní.“ KELSEN, Hans: General Theory of Law and State. Cambridge, Massachusetts: Harvard University Press, 1949, s. 41-42. Z tohoto Kelsenova předpokladu Stone dovozuje, že otázka platnosti je alespoň částečně závislá na faktickém stavu (celkové efektivitě právního systému) - viz STONE, Julius: Legal System and Lawyers'Reasoning. Sydney: Maitland Publications Pty., Ltd., 1968, s. 104.

19 VINX, Lars: The Guardian of the Constitution... Op. cit., s. 7.

20 KELSEN, Hans: Wesen und Entwicklung... Op. cit., s. 1487.

$21 \mathrm{~K}$ individuálním normám řadí Kelsen i právní jednání (zejména v soukromém právu), kterým si účastníci vlastní stanovují individuální normy (opět v mezích stanovených zákony). Podrobněji viz KELSEN, Hans: Ryzi nauka právní... Op. cit., s. 35 a násl.

22 SCHMITT, Carl: Der Hüter der Verfassung... Op. cit., s. 78. Jak známo, rovněž americký Nejvyšší soud však od roku 1936 přestal rušit právní předpisy upravující soukromoprávní vztahy a př́ekonal tak období charakterizované př́stupem Nejvyššího soudu v případu Lochner v. New York 198 U.S. 45.

23 KELSEN, Hans: Wesen und Entwicklung... Op. cit., s. 1486.

24 Ibid., s. 1502.

25 Ibid., s. 1505-1506. O „legislativní funkci soudnictvi““ hovoří H. Kelsen i v Obecné teorii práva a státu, když kromě funkce negativního zákonodárce zde řadí i precedenční působení soudních rozhodnutí - KELSEN, Hans: General Theory of Law and State... Op. cit., s. 272. 
legislativy později přidává i argument historický. Ve své Obecné teorii státu a práva z roku 1949 Kelsen uvádí, že ústavní přezkum je výrazem nedůvěry v zákonodárnou a výkonnou moc a naopak důvěry v soudnictví, které získalo atribut nezávislosti na panovníkovi. Zdroj nedůvěry tento autor vnímá v dědictví absolutismu, v němž panovník vykonával přímo zákonodárnou i výkonnou moc. $\mathrm{Z}$ toho důvodu se podle Kelsena zrodilo přesvědčení, že ochránci individuálních práv mohou být v ústavním státě pouze soudy. ${ }^{26}$

Jak již bylo uvedeno výše, Schmitt s Kelsenovými závěry zásadně nesouhlasí. Existují tři linie argumentace, které Schmitta přivádějí k závěru, že strážcem ústavy v uvedeném př́ípadě by měl být říšský prezident, nikoliv soud. První představuje odmítnutí ústavních soudů jako orgánů ve své podstatě nedemokratických, kterým rozhodování sporů, o jejichž řešení nepanuje shoda, nemůže být svěřeno. ${ }^{27}$ Schmitt hovoří o nebezpečí vzniku druhé komory parlamentu, obsazené nikým nevolenými úředníky, kteří nemohou být navíc odvoláni. $\mathrm{Z}$ těchto úředníků - soudců - by se stala aristokracie v talárech. ${ }^{28}$

Druhým argumentem, který připomíná David Dyzenhaus, je odlišování normálního a výjimečného stavu. I kdyby v běžných poměrech soudy rozhodovaly právní spory, výjimečná situace, o kterou v daném př́ípadě šlo, vyžaduje politické řešení, které je na rozhodnutí prezidenta. ${ }^{29}$

Třetí argument spočívá v existenci silného postavení prezidenta, legitimovaného př́ímou volbou, který je sice orgánem politickým, nikoliv však nutně spojeným s konkrétní politickou stranou. Proto je vhodnější k řešení politických konfliktů nejen než soud, ale i než parlament, který se stranickým hašteřením dostává do politické paralýzy. ${ }^{30}$ Nutnost silnějšího postavení politických orgánů státu zdůvodňuje svým odlišováním minimálního a totálního státu. Zatímco $\mathrm{v}$ devatenáctém století stát nezasahoval do ekonomiky, náboženství a soukromého života, ve století dvacátém je to stát, který organizuje hospodářství, sociální zabezpečení, a stále více i kulturu a vše, co se týká společnosti. ${ }^{31}$

Přechod od charakteristiky totálního státu k nutnosti silného prezidenta jako strážce ústavy je poměrně obtížně vysledovatelný a je i předmětem Kelsenovy kritiky. ${ }^{32}$ V prvé řadě je třeba zmínit, že přímo volený prezident je podle Schmitta vhodným reprezentantem lidu jakožto homogenního útvaru, který zakládá stát (a tedy i jeho právní řád). ${ }^{33}$ Zdá se, že klíčové pro Schmitta $\mathrm{v}$ jeho zdůvodnění silného postavení prezidenta

26 KELSEN, Hans: General Theory of Law and State... Op. cit., s. 281.

27 VINX, Lars: Introduction... Op. cit., s. 9.

28 SCHMITT, Carl: Der Hüter der Verfassung... Op. cit., s. 156.

29 DYZENHAUS, David: States of Emergency. In ROSENFELD, Michel - SAJÓ, András (eds.): The Oxford Handbook of Comparative Constitutional Law. Oxford: Oxford University Press, 2012, s. 449.

30 VINX, Lars: Introduction... Op. cit., s. 10.

31 SCHMITT, Carl: Der Hüter der Verfassung... Op. cit., s. 78-79. Avšak jak správně poznamenává H. Kelsen, liberální stát devatenáctého století se zrodil jako reakce na absolutistický, a tedy rovněž totální, stát (KELSEN, Hans: Wer soll der Hüter der Verfassung sein... Op. cit., s. 1556).

32 Podle Kelsena je možné vést různé spory o podobu garance ústavnosti (má-li být preventivní nebo represivní, jakou roli má hrát osobní odpovědnost těch, kteří protiústavní úpravu schválili, atd.). Jedna věc však z povahy věci musí být dle tohoto autora zřejmá všem: pravomoc kontrolovat ústavnost nemůže být svěřena těm orgánům, které zároveň mají této kontrole podléhat. Jedná se o projev zásady, že nikdo nemá být soudcem ve své vlastní věci. (KELSEN, Hans: Wer soll der Hüter der Verfassung sein... Op. cit., s. 1534).

33 DYZENHAUS, David: Legality and Legitimacy... Op. cit., s. 118. 
je jím vnímaná krize parlamentarismu a nevýhody soudů při řešení politických otázek, prričemž instituce říšského prezidenta zbývá jako poslední a podle $S$ chmitta nejméně kontroverzní. Vedle toho se však rovněž zdá, že model komisařské diktatury (jejímž prríkladem je napríklad diktátor - magistratus extraordinarius - v období rímské republiky) je Schmittovi při řešení politických krizí ve státě blízký. Tuto skutečnost však Hans Kelsen př́mo nekritizuje, nebot' se chce, dle vlastních slov, zaměřit na normativní stránku a logiku takovéto ústavy, nikoliv na související politické otázky. ${ }^{34}$

Ponechme proto stranou popis preferencí obou autorů $\mathrm{k}$ jednotlivým institucím, zaměřme se nyní na otázku, jak se Kelsen vypořádává s kritikou, že soudy nemají legitimitu na zasahování do politiky. Podle Vinxe je třeba Kelsenovu teorii ústavního přezkumu číst v souvislosti s jeho teorií demokracie. Pro funkci ústavních soudů je klíčové respektovat hierarchicky uspořádaný právní systém, jakož i pravomoci, které byly soudům svěřeny a které soudy, stejně jako jiné orgány, nemohou překračovat. Přitom však Kelsen uznává, že hodnocení ústavnosti je při vágní formulaci ústavních textů často předmětem neshody. Domnívám se tedy, že ani Kelsenovo úsilí o propojení záruk ústavnosti a demokracie jednoznačně nevyvrací klíčové argumenty kritikủ (včetně Schmitta), že existuje riziko, že se ústavní soudy stanou ,náhradním suverénem“, budou-li jejich soudci ústavě přisuzovat vlastní význam. ${ }^{35}$ Řešení nespatřuji ani v Kelsenově apelu na ústavní soudy, aby svá rozhodnutí neopíraly o vágní pojmy, jako je spravedlnost, rovnost, svoboda. ${ }^{36}$

Naopak, roli ústavních soudů popisovanou Kelsenem lze hodnotit jako ne zcela jasnou, nebot' na jedné straně mají být optimálními strážci ústavy, protože jsou k tomu lépe vybaveny než orgány rozhodující primárně na základě politických úvah (prezident, vláda, parlament), na straně druhé se však konstatuje, že každé rozhodnutí vzešlé z nikoliv pouze mechanicky aplikovaného zákona s sebou nese nutnost diskrece soudů, a tedy jejich politické rozhodnutí. ${ }^{37}$ Jak správně upozorňuje Dyzenhaus, je skutečně sporné, zda lze sjednotit obhajobu inherentně politického rozhodování soudců s kritikou politicky rozhodujícího prezidenta. ${ }^{38}$

\section{ÚSTAVNÍ PŘEZKUM ZÁKONU゚ A ROLE SOUDNÍ MOCI V SOUČASNOSTI}

Úloze soudů v demokratickém státě spočívající v triadickém modelu řešení sporů je věnováno množství historické i recentní odborné literatury. ${ }^{39}$ Postavení soudní

34 KELSEN, Hans: Wer soll der Hüter der Verfassung sein... Op. cit., s. 1572-1573.

35 VINX, Lars: Hans Kelsen's Theory of Law... Op. cit., s. 156-157.

36 KELSEN, Hans: Wer soll der Hüter der Verfassung sein... Op. cit., s. 1549-1550 a komentár k této pasáži v: VINX, Lars: Hans Kelsen's Theory of Law... Op. cit., s. 164.

37 Shodně VINX, Lars: Hans Kelsen 's Theory of Law... Op. cit., s. 148. Jak jsem poukázal výše, relativizace striktního odlišování právních otázek jako úlohy soudů a politických otázek jako úlohy zákonodárce stojí v jádru Kelsenovy obrany vůči kritice ze strany C. Schmitta.

38 DYZENHAUS, David: Legality and Legitimacy... Op. cit., s. 122.

39 Na počátku 21. století téma judicializace politiky popisoval např. A. Stone Sweet a M. Shapiro: STONE SWEET, Alec: Governing with Judges. Constitutional Politics in Europe. Oxford: Oxford University Press, 
moci při řešení sporů o právo mezi dvěma stranami však nelze ztotožňovat s ústavním přezkumem zákonů. Zde je role soudů odlišná, nedochází v pravém smyslu k aplikaci práva na konkrétní skutkový stav, nýbrž o přezkum právních otázek. Je však třeba se ptát, zda jsou soudy skutečně výlučnými orgány, které by se kontrolou ústavnosti měly zabývat. Autoři odpovídající kladně na tuto otázku odkazují zejména na argumenty podané Johnem Marshallem v prípadu Marbury versus Madison, ${ }^{40}$ které podle Stephena Breyera spočívaly na třech myšlenkách: 1) klíčové roli ústavy jakožto právního předpisu nejvyšší právní síly, 2) odbornosti soudu a 3) potřebě zabránit nikterak neomezenému zákonodárci. ${ }^{41}$

Přestože význam ústavního soudnictví jako takového již v současných liberálních demokraciích není zpochybňován, kritické názory se místy objevují ve vztahu ke konkrétním rolím, které na sebe ústavní soudy berou, pokud jde o například o rozhodování otázek, které by měly být předmětem politiky a měly by náležet bud' přímo lidu anebo demokraticky zvoleným orgánům. Tak například Ran Hirschl vnímá příklon k juristokracii, ${ }^{42}$ Victor Ferreres Comella sice uznává, že evropský model koncentrovaného ústavního soudnictví plnil důležitou roli pro prosazení koncepce právního státu, avšak v současném heterarchickém modelu vládnutí v Evropě je oslabován posilováním role obecných soudů oproti soudům ústavním. ${ }^{43}$ Typickým př́kladem představuje pravomoc nižších soudů předkládat předběžné otázky k Soudnímu dvoru Evropské unie, čímž mohou zpochybňovat judikaturu nejvyšších soudních instancí ve státě.

V této části se pokusím srovnat argumenty př́znivců a odpůrců silné role ústavního soudnictví ve státě a následně je porovnat s Kelsenovými argumenty týkajícími se role ústavního soudu. ${ }^{44}$ Hovořím-li o silné roli ústavních soudo̊, jako východisko uvažuji klasifikaci Stephena Gardbauma, který vychází ze tří modelů fungování ústavního soudnictví a jeho vztahu k zákonodárné moci. ${ }^{45}$ První představuje klasickou britskou

2000, s. 12 a n. SHAPIRO, Martin - STONE SWEET, Alec: On Law, Politics, and Judicialization. Oxford: Oxford University Press, 2002, s. 57 a n.

40 Marbury v. Madison 5 U.S. 137, 177 (1803). K českému komentáři k případu viz ANTOŠ, Marek: Slavný př́ípad Marbury vs. Madison aktuální i po dvou stoletích. Jurisprudence, č. 1/2010, s. 38-42.

41 BREYER, Stephen: Making Our Democracy Work. A Judge’s View. New York: Alfred A. Knopf, 2010, s. 12 a násl.

42 HIRSCHL, Ran: Towards Juristocracy: The Origins and Consequences of the New Constitutionalism. Cambridge: Harvard University Press, 2004. Jak však připomíná H. Smekal, Hirschlovo pojetí se týká spíše vlády právníků (jurists) než soudců (judges) - viz SMEKAL, Hubert: Soudcokracie, nebo judicializace politiky? In SMEKAL, Hubert - POSPÍŠIL, Ivo (eds.): Soudcokracie nebo judicializace politiky: vztah práva a politiky (nejen) v časech krize. Brno: Masarykova Univerzita, 2013, s. 13. Přesto se však ústřední teze knihy týká role ústavního přezkumu ve vztahu k politickým a ekonomickým elitám - viz CLOSA, Carlos: Book Review: HIRSCHL, Ran: Towards Juristocracy: The Origins and Consequences of the New Constitutionalism. Cambridge: Harvard University Press, 2004. International Journal of Constitutional Law, sv. 3, č. 4/2006, s. 582.

43 FERRERES COMELLA, Víctor: Constitutional Courts and Democratic Values. A European Perspective. New Haven, London: Yale University Press, 2009, s. 156-157.

44 Velké množství, ač nestrukturovaných, argumentů lze nalézt v článku: HÜBNER MENDES, Conrado: Is It All about the Last Word? Legisprudence, sv. 3, č. 1/2009, s. 69-110.

45 GARDBAUM, Stephen: The New Commonwealth Model of Constitutionalism. The American Journal of International Law, sv. 49, 2001, s. 707 a nás1., GARDBAUM, Stephen: Reassessing the new Commonwealth model of constitutionalism. International Journal of Constitutional Law, sv. 8, 2010, s. 167 a násl. Komplexně viz GARDBAUM, Stephen: The New Commonwealth Model of Constitutionalism. Theory and Practice. Cambridge: Cambridge University Press, 2013, s. 25 a násl. 
koncepci suverenity parlamentu opírající se o teorii politického konstitucionalismu. ${ }^{46}$ Na opačném pólu stojí silný model ústavního soudnictví ve státech uznávajících širokou pravomoc soudů přezkoumávat ústavnost zákonů (Gardbaum tento model nazývá právním konstitucionalismem) ${ }^{47}$ Konečně třetí model popisovaný jako „new Commonwealth model of constitutionalism" vychází z ústavních změn Kanady (1982), Nového Zélandu (1990) a Velké Británie (1998), které se pokusily nastolit určitou rovnováhu ve vztahu svých ústavních soudů a parlamentů. ${ }^{48}$

Klasickým argumentem ve prospěch ústavního přezkumu je teze o nutnosti ochrany práv jednotlivců a menšin před tyranií většiny, kterou nalezneme již v Tocquevillově Demokracii v Americe. ${ }^{49}$ Autor tento pojem rozebírá podrobně v kontextu republikánského zřízení Spojených států a upozorňuje již na Jamese Madisona, podle něhož: ,je důležité chránit společnost nejen před útlakem vládců, nýbrž i jednu část společnosti před nespravedlností působenou jinou částí společnosti. “50 Jeremy Waldron, známý svým kritickým postojem k přezkumu zákonů ústavními soudy, však proti této tezi uvádí, že rozhodování většiny nelze až na výjimky označovat jako „tyranii většiny“. Právě naopak, je podstatou demokracie a tudíž legitimní, že většina dokáže oproti menšině svou vůli prosadit. Pokud jde o potenciální ohrožení základních práv menšin, je podle Waldrona třeba rozlišovat, zda se jedná o menšinu, která je určitým rozhodnutím znevýhodněna, anebo o menšinu decisní, tj. menšinu v rozhodovacím procesu. ${ }^{51}$ Pouze za situace, kdy se menšina postižená rozhodnutím kryje s menšinou účastníků rozhodovacího procesu, mohou většinová rozhodnutí vést k nepřijatelnému zasahování do práv. S odkazem na tohoto autora je však třeba připomenout, že patrně nepůjde o zcela běžné situace. Např́klad při diskusích o důsledcích segregace ve Spojených státech se ukazuje, že vyrovnání podmínek znevýhodněným občanům náležejícím k černošské populaci (např. afirmativní akci) hájí často i zástupci většinového obyvatelstva. ${ }^{52}$

Rozpracování a modernější verzi argumentu tyranií většiny nalezneme u procedurální teorie demokracie, zejména v klasickém díle Johna Harta Elyho ${ }^{53}$ Hlavní úloha ústavních soudů spočívá $\mathbf{v}$ ochraně politických procesů před selháními, která by ústila ve vytváření uzavřených a izolovaných menšin (discrete and insular minorities), jež by neměly možnost přeměnit se v budoucnu ve většinu. Pojem uzavřená a izolovaná menšina přebírá Ely z odůvodnění př́ípadu United States v. Carolene Products z roku 1938 ze slavné poznámky pod čarou č. 4 - Footnote 4, v jejímž třetím odstavci je

46 BELLAMY, Richard: Political Constitutionalism: A Republican Defence of the Constitutionality of Democracy. Cambridge: Cambridge University Press, 2007.

47 GARDBAUM, Stephen: The New Commonwealth Model of Constitutionalism... Op. cit., s. 22.

48 Podrobně ke komentáŕi ke Gardbaumovu dílu srov. KING, Jeff: Rights and Rule of Law in Third Way Constitutionalism (review of Stephen Gardbaum's The New Commonwealth Model of Constitutionalism). Constitutional Commentary, sv. 30, 2014, s. 101-126.

49 TOCQUEVILLE, Alexis de: Democracy in America. Sv. I. New York: Alfred A. Knopf, 1991, s. 258 a násl.

50 Ibid., s. 268.

51 WALDRON, Jeremy: The Core of the Case against Judicial Review. The Yale Law Journal, sv. 115, 2006, s. 1397 a násl.

52 Ibid., s. 1401 a násl.

53 ELY, John Hart: Democracy and Distrust. A Theory of Judicial Review. Cambridge, London: Harvard University Press, 1980. 
explicitně zmíněna možnost př́snějšího soudního přezkumu zákonů v případech, kdy by „předsudky proti uzavřeným a izolovaným menšinám představovaly podmínku, jež by vážně omezovala výkon politických procesů...".54 Úkolem soudů podle Elyho je „uvolnit kanály pro politickou změnu“, a usnadnit tím reprezentaci menšin. ${ }^{55}$ Podstatou amerického konstitucionalismu podle tohoto autora není orientace na substantivní hodnoty, nýbrž na procesy posílení reprezentace..$^{56}$

Další skupina argumentů se zaměřuje na požadavek existence interpreta chránícího ústavu a právní stát (v těchto úvahách se již přímo odráží myšlenka o strážci ústavy). Podle Fredericka Schauera a Larryho Alexandera slouží ústavní soudnictví primárně k urovnávání sporů a ústavní soudy jsou orgány, které nejlépe plní funkci autoritativního výkladu ústavy. ${ }^{57}$ Podobně uvažuje i současný soudce Nejvyššího soudu USA Stephen Breyer, který s odkazem na Hamiltona spatřuje výhody soudu v tom, že má ze všech orgánů, které by potenciálně mohly působit jako strážci ústavy, nejmenší potenciál zneužití pravomocí. ${ }^{58}$ Ústavní soudy tak primárně působí v roli vetujícího orgánu (kelsenovského negativního zákonodárce), který působí jako protiváha neomezené zákonodárné moci. ${ }^{59}$

Argumenty pro a proti ústavnímu přezkumu se nezř́íka míjejí v tom, že zastánci silného soudu či naopak minimálně omezovaného zákonodárce vnímají v druhém orgánu ohrožení. Na jedné straně stojí zastánci otevřených demokratických debat v parlamentu obávající se zásahů ze strany nikým nevolených a neodpovědných soudců, na straně druhé stojí autoři vnímající soudce jako profesně a snad i eticky způsobilejší ve srovnání s netransparentním rozhodováním často pod vlivem různých zájmových skupin v parlamentu. ${ }^{60}$ Kritikové parlamentních rozhodovacích procedur navíc připomínají známý teorém Kennetha Arrowa, z něhož plyne, že rozhodování v zastupitelských orgánech nemusí vždy odrážet vưli většiny. Přesnější než o tyranii většiny je tedy hovořit o tyranii dobře informovaných menšin znalých parlamentních procedur. ${ }^{61}$

Jeden proud současné právní teorie se zaměřuje při popisu debat o střetu ústavního soudu a zákonodárce na hledání orgánu, který by měl v těchto sporech „poslední slovo“, tedy, jehož rozhodnutí by bylo finální. Toto dilema rovněž reflektuje spor Kelsena

54 Rozhodnutí Nejvyššího soudu USA ze dne 25. 8. 1938 ve věci United States v. Carolene Products 304 U.S. 144. Komentár k poznámce pod čarou č. 4 (Footnote 4) viz ELY, John Hart: Democracy and Distrust... Op. cit., s. 75 a násl.

55 Srov. kapitolu 5 (Clearing the Channels of Political Change) a kapitolu 6 (Facilitating the Representation of Minorities) monografie: ELY, John Hart: Democracy and Distrust... Op. cit., s. 105 a násl.

56 Ibid., s. 87-88.

$57 \mathrm{Z}$ toho vyvozují tito autoři požadavek na nadřazenost soudů (judicial supremacy) při interpretaci ústavy nad všemi dalšími státními orgány - srov. ALEXANDER, Larry, SCHAUER, Frederick: On Extrajudicial Constitutional Interpretation. Harvard Law Review, sv. 110, 1997, s. 1359.

58 BREYER, Stephen: Making Our Democracy Work... Op. cit., s. 215.

59 HÜBNER MENDES, Conrado: Is It All about the Last Word?... Op. cit., s. 87.

${ }^{60}$ Kriticky se k roli soudce jakožto morálního arbitra vyjádřil na konferenci Právo a politika: Weyrovy dny právní teorie 2017 konané ve dnech 1. a 2. června 2017 Tomáš Sobek.

61 HÜBNER MENDES, Conrado: Is It All about the Last Word?... Op. cit., s. 106. V České republice v posledních letech narůstá počet parlamentních obstrukcí, jejichž legitimita je sporná. Na jednu stranu představují překážku řádného fungování parlamentu, potažmo realizace vládní politiky, na straně druhé projev legitimního práva opozice kritizovat vládu. Jako v jiných otázkách jde o věc míry. Srov. k tomu WINTR, Jan: Česká parlamentni kultura. Praha: Auditorium, 2010, s. 222. 
se Schmittem. Orgán, který má poslední slovo, se má stát strážcem ústavy a tato jeho funkce nemá být ze strany jiných orgánů zpochybňována. Oproti tomu stojí teorie soudního dialogu, hledající usmíření mezi oběma krajními extrémy. ${ }^{62}$ Moderní teorii představil Conrad Hübner Mendes, který v př́ípadě konfliktů zákonodárce s ústavním soudem hovoří o ,prozatímním posledním slovu“ (provisional last say) nebo také o jednotlivých ,procesních kolech“ (procedural rounds) a prripodobn̆uje spor, kdy soudy a parlamenty opakovaně rozhodují jeden obtížný prrípad, k tenisové výměně. ${ }^{63}$ Co ale v případě př́lišs zdlouhavé výměny názorů, kdy se spravedlnosti ani jedné ze stran nedostává (platí maxima justice delayed is justice denied). Hübner Mendes nalézá řešení tohoto problému v tezi, že převážit by měla argumentace odpovídající „,veřejnému rozumu“ (public reason), ${ }^{64}$ přičemž tento pojem přebírá od Rawlse. ${ }^{65} \mathrm{Jak}$ soudy, tak parlamenty se pohybují v určitém společenském prostředí a jejich závěry jsou veřejností posuzovány. Přri úvahách o uspořádání vrcholných institucí ve státě tedy nemůžeme ignorovat skutečnost, že veřejné instituce a právní regulace, kterou vytvářejí, se nevyskytují ve vakuu.

Častá odpověd' na problém aktivistického soudního rozhodování je volání po sebeomezení soudu. Americký autor Alexander Bickel, známý svou analýzou politického rozhodování soudů ${ }^{66}$ prosazuje na př́íladu Nejvyššího soudu USA, ,pasivistický“ soud (passivist court), který rozumně využívá možností, jaké jsou dány doktrínami political question, case and controversy, ripeness a jinými za účelem posílení legitimity a přesvědčivosti svých rozhodnutí. ${ }^{67}$ Jak připomíná Mark Tushnet, ,slabý“ model ústavního přezkumu, v němž nemají soudy poslední slovo, nemusí být známkou neefektivní ochrany určité skupiny práv, například práv sociálních. ${ }^{68}$

V podobném duchu se vyslovuje i Cass Sunstein, když obhajuje takový př́ístup ústavních soudů, které se orientují výlučně na danou kauzu a formulují své ratio decidendi úzce a v závislosti na skutkových okolnostech prrípadu. Toto rozhodování nazývá minimalismem v rozhodování (decisional minimalism). ${ }^{69}$ Zároveň Sunstein uvádí výhody, které má spíše stručná a ne př́liš hluboká argumentace: nerozhodovat o všech otázkách, které s daným př́ípadem souvisejí, je důležité nejen vzhledem k roz-

$62 \mathrm{Z}$ množství literatury $\mathrm{k}$ tomuto tématu srov. přehledový článek B. Friedmanna: FRIEDMANN, Barry: Dialogue and Judicial Review. Michigan Law Review, sv. 91, 1993, s. 577-682.

63 HÜBNER MENDES, Conrado: Not the Last Word, But Dialogue: Deliberative Separation of Powers II. Legisprudence, sv. 3, č. 2/2009, s. 223. Paralelu o tenisové výměně přebírá C. Hübner Mendes od B. Friedmanna, který v tomto ohledu uvažuje o utváření a směrování veřejné debaty o zásadních otázkách ze strany soudů - srov. podrobněji: FRIEDMANN, Barry: Dialogue and Judicial Review... Op. cit., s. 669.

${ }^{64}$ HÜBNER MENDES, Conrado: Neither Dialogue Nor the Last Word: Deliberative Separation of Powers III. Legisprudence, sv. 1, č. 5/2012, s. 25.

65 „Veřejný rozum je charakteristikou demokratického společenství: je to rozum občanů, tedy těch sdílejících status rovnosti a občanství. Předmětem jejich rozumu je dobro společnosti..." Cit dle: RAWLS, John: Political Liberalism. New York: Columbia University Press, 1993, s. 213.

66 BICKEL, Alexander: The Least Dangerous Branch... Op. cit.

67 BICKEL, Alexander: Foreword - The Passive Virtues. Harvard Law Review, sv. 75, 1961, s. 40-79.

68 TUSHNET, Mark: Weak Courts, Strong Rights: Judicial Review and Social Welfare Rights in Comparative Constitutional Law. Princeton, Oxford: Princeton University Press, 2008, s. 264.

69 SUNSTEIN, Cass. Foreword: Leaving Things Undecided. The Supreme Court 1995 Term. Harvard Law Review, sv. 110, 1996, s. 7. 
šiřování prostoru pro demokratické rozhodování, ale také z pragmatických důvodů minimalizace chybných závěrů soudu..$^{70}$ Uvedený autor rozlišuje odůvodnění, která jsou úzce zaměřená na daný skutkový stav, anebo naopak široká, dopadající na velký okruh př́padů. ${ }^{71} \mathrm{Z}$ jiného pohledu můžeme vnímat rozhodnutí se stručným odůvodněním, ${ }^{72}$ anebo naopak s velmi hlubokým sdělením teoretických základů. ${ }^{73} \mathrm{I}$ v České republice je možné hodnotit ššři a hloubku odůvodnění soudních rozhodnutí, za př́kladný př́stup minimalismu v rozhodování je možné označit nedávné rozhodnutí českého Ústavního soudu ve věci imunity poslance za projevy učiněné na sociální síti Facebook. V tomto rozhodnutí Ústavní soud mimo jiné uvádí: „Za projev ve svých komorách a jejich orgánech tedy nelze poslance ani senátora trestně stíhat, ani proti němu zahájit správní ř́zení, nicméně komora, jejímž je dotčený poslanec či senátor členem, může tohoto poslance či senátora kárně stíhat a následně uložit kárné opatření. Trestněprávní a správněprávní odpovědnost poslanců a senátorů je tak nahrazena specifickou disciplinární odpovědností před př́íslušnou komorou. V této souvislosti Ústavní soud dodává, že k tomu, zda čl. 27 odst. 2 Ústavy vylučuje i civilní žaloby vůči poslanci za jeho projevy učiněné v Poslanecké sněmovně nebo v jejich orgánech, se Ústavni soud v této věci nevyjadřuje, nebot' zodpovězeni této otázky není pro projednávaný prípad nezbytné (zvýrazněno autorem).“74

Relativně novou otázkou týkající se ochrany ústavnosti, která se ještě intenzivněji dotýká legitimity ústavního přezkumu, pak přináší přezkum ústavnosti ústavních zákonů ze strany soudů. ${ }^{75} \mathrm{~K}$ této problematice poznamenávám, že v Kelsenových textech, s nimiž jsem se měl možnost seznámit, se tato situace neuvažuje. V základech jeho teorie bychom sice mohli nalézt určité indicie souladu ochrany materiálního jádra ústavy nebot' samotné rozdělení ústavního pořádku na materiální jádro a „zbývající“ část není v rozporu se stupňovitou výstavbou právního řádu ani s představou základní normy, nicméně jednoznačný závěr o Kelsenově preferenci takovéto role ústavních soudů podle mého názoru $\mathrm{v}$ jeho díle chybí.

70 Ibid., s. 16 a násl.

71 C. Sunstein uvádí, že v př́ípad Dred Scott v. Sanford 60 U.S. 393 (1857) formuloval Nejvyšší soud USA své závěry tak široce, že se pokusil obsáhnout celé pojetí otroctví černošského obyvatelstva v americké ústavě. SUNSTEIN, Cass. Foreword: Leaving Things Undecided... Op. cit., s. 24.

72 Většina rozhodnutí odmítající certiorari, kdy se Nejvyšší soud nezabývá danou kauzou, je takto odůvodněna - SUNSTEIN, Cass. Foreword: Leaving Things Undecided... Op. cit., s. 23.

73 C. Sunstein zde zmiňuje podrobně odůvodněné většinové stanovisko, které napsala R. B. Ginsburgová, v př́ípadu United States v. Virginia, 518 U.S. 515 (1996). V tomto př́padu soud konstatoval porušení zákazu diskriminace z důvodu pohlaví, nebot' na vojenské akademii nemohly studovat ženy. SUNSTEIN, Cass. Foreword: Leaving Things Undecided... Op. cit., s. 73.

74 Nález Ústavního soudu sp. zn. I. ÚS 3018/14 ze dne 16. 6. 2015, odst. 23 odůvodnění rozhodnutí.

75 Podrobně v recentní odborné literatuře viz PREUSS, Ondřej: Klauzule věčnosti (Je možné odstranit liberální demokracii?). Plzeň: Aleš Čeněk, 2015. GRINC, Jan: Přezkum ústavních zákonů v Německu a Rakousku. Jurisprudence, sv. 19, č. 1/2010, s. 31-37. 


\section{ZÁVĚR}

Při hodnocení ideového sporu mezi Kelsenem a Schmittem je třeba na prvním místě poukázat na fakt, že ústavní systém Výmarské republiky s prezidentem hrajícím velmi silnou roli neobstál. ${ }^{76}$ Pozdější vývoj však ukázal, že všechny Kelsenovy argumenty ve prospěch silného ústavního soudu rovněž zcela neobstojí. Dủvody spočívají podle mého názoru ve výše uvedených proměnách, $\mathrm{k}$ nimž ve veřejném právu docházelo od druhé poloviny minulého století. Mění-li se veřejné právo, je logické, že se mění i očekávání a funkce ústavních soudů. Pokud však jde o samotné utváření evropského kontinentálního modelu ústavního přezkumu, za jehož vzor bychom mohli považovat poválečné pojetí ústavního státu Spolkové republiky Německo (a v návaznosti na něj modely řady dalších států), v tomto ohledu nelze roli Kelsena snižovat. ${ }^{77}$ Přesto je třeba souhlasit s Markem Antošem, ${ }^{78}$ Susanne Baer ${ }^{79}$ a dalšími autory v tom, že role ústavních soudů se postupně mění. Jsme svědky nejrůznějších interpretativních výroků soudu, ${ }^{80}$ př́ípadů, kdy ústavní soud zruší pouze část právního předpisu, čímž změní právní normy v něm obsažené, ${ }^{81}$ př́padně ex ante stanoví parametry či limity budoucí právní úpravy, která má být přijata po zrušení protiústavního předpisu. ${ }^{82}$ Uvedené př́iklady naznačují, že výkon pravomocí je současnými ústavními soudy chápán šiřreji než pouhý negativní zákonodárce. Mimo jiné z těchto důvodů se kritikové široce pojímané kontroly ústavnosti domnívají, že finální rozhodnutí by neměl mít ve všech př́padech ústavní soud.

76 DYZENHAUS, David: Legality and Legitimacy... Op. cit., s. 17.

77 ROSENFELD, Michel: The Rule of Law and the Legitimacy of Constitutional Democracy. Southern California Law Review, sv. 74, 2001, s. 1329.

78 ANTOŠ, Marek: Současné ústavní soudnictví... Op. cit., s. 40-41.

79 BAER, Susanne: Rights under Pressure: practising constitutional law in turbulent times. LSE Public Lectures and Events. 10. května 2016, přednáška dostupná na internetu: http://www.lse.ac.uk/website-archive/ newsAndMedia/videoAndAudio/channels/publicLecturesAndEvents/Home.aspx.

80 Zvláště kontroverzní typ výroku se nachází v nálezu Ústavního soudu sp. zn. Pl. ÚS 28/13 ze dne 10. 7. 2014, týkajícím se platů soudců. Platová základna pro výpočet platů soudců ve výši 2,75násobek průměrné měsíční mzdy byla obsažena v ustanovení $§ 3$ odst. 3 zák. č. 236/1995 Sb. o platu některých představitelů státních orgánů a soudců. Toto ustanovení se však týkalo rovněž představitelů vrcholných státních orgánů, nejen soudců. Výrok Ústavního soudu v tomto rozhodnutí zněl: „Ustanovení obsažené v $§ 3$ odst. 3 zákona č. 236/1995 Sb., o platu a dalších náležitostech spojených s výkonem funkce představitelů státní moci a některých státních orgánů a soudců a poslanců Evropského parlamentu, naposledy ve znění zákona č. 11/2013 Sb., vyjádřené slovem „2,75násobek“, pokud se týká soudců okresních, krajských, vrchních soudů, Nejvyššího soudu a Nejvyššího správního soudu, se ruší uplynutím dne 31. prosince 2014.“

81 Z české praxe lze uvést př́pad zrušení minimální výše pokuty pro živnostníky, čímž došlo k přetvoření sankce právní normy, která nově pozbyla minimální hranici. Nález Ústavního soudu ze dne 13. 8. 2012 sp. zn. Pl. ÚS 3/02 zrušil spodní hranici pokuty ve stavebním zákoně z důvodu, že v určitých případech může mít na živnostníky likvidační charakter. Podobná argumentace se objevuje v nálezu k sankci za nelegální zaměstnávání (tzv. švarcsystém) - nález Ústavního soudu ze dne sp. zn. Pl. ÚS 52/13 ze dne 9. 9. 2014.

82 Ve výše uvedeném nálezu týkajícím se platů soudců dovodil Ústavní soud mimo jiné: S ohledem na shora uvedené důvody tak není v současné době již prostor pro restriktivní zásahy do relativního poměru zakotveného v 33 odst. 3, jak byl založen zákonem č. 309/2002 Sb. (na úrovni 3násobku). Pro přijetí ústavně konformní relace mezi průměrnou mzdou $\mathrm{v}$ nepodnikatelské sféře a platovou základnou soudců stanovil Ústavní soud odklad vykonatelnosti nálezu po přiměřenou dobu, která postačuje k řádnému zákonodárnému procesu této legislativně jednoduché změny (nález Ústavního soudu sp. zn. Pl. ÚS 28/13 (platy soudců XV.) ze dne 10. 7. 2014, odst. 80). Zákonodárce na tento nález reagoval novelou 359/2014 Sb., kterou soudcům ve smyslu výše uvedeného limitu v rozhodnutí Ústavního soudu stanovil platovou základnu ve výši 3násobku průměrné měsíční mzdy. 
Pozoruhodným faktem je, že oba autoři sporu o strážce ústavy prezentují orgány, které v jejich očích představují ideál ochrany ústavnosti, jako nepolitické. Méně kontroverzně tato teze působí u Hanse Kelsena, který založil svou ryzí nauku právní na oddělení práva a politiky, naopak v př́ípadě Schmitta tento argument obtížně zapadá do jeho teorie, $v$ níž je veškeré právo v zásadě rozšířením politiky. ${ }^{83}$ Historické argumenty o fungování instituce hlavy státu na jedné straně a soudců na straně druhé, o které oba autoři své teze opírají, rovněž nemají podle mého názoru na současný výkon jejich funkcí zásadní vliv. Jak bylo řečeno výše, role ústavních orgánů se od počátku 20. století podstatně proměnila. Samotné tvrzení o ústavním zakotvení obou těchto orgánů jako neutrálních podle mého názoru nestačí k prokázání jejich faktické nezávislosti. Schmitt hovoří o zatížení soudní moci rozhodováním o politických otázkách ${ }^{84}$ a připomíná i možný exces soudní moci v podobě úmyslného politického rozhodování nevolených soudců vrcholných soudi̊. ${ }^{85}$ Kelsen zase zpochybňuje tezi o nestranickosti prezidenta, nebot' i př́mo volený prezident může mít podporu parlamentní ale i mimoparlamentní strany. ${ }^{86}$ Ostatně posledně zmiňovaný př́pad je $\mathrm{v}$ českém prostředí znám, vedl k problematickému a kritizovanému jmenování vlády „odborníků“ prezidentem Zemanem v červnu roku $2013 .{ }^{87}$ Lze tedy shrnout, že s vědomím fungování vrcholných orgánů je potřeba otevřeně přiznat možnost politického rozhodování hlavy státu, ale i ústavních soudců. ${ }^{88}$

Přestože ústavní soudy v Kelsenových časech a nyní chápou svou vlastní úlohu jinak, některé obavy z adekvátního nastavení rovnováhy mezi zákonodárnou a soudní mocí jsou z Kelsenova díla patrné. Kelsen například varoval před používáním neurčitých pojmů a odůvodňováním rozhodnutí ústavních soudů abstraktními hodnotami. ${ }^{89}$ Tím spíše by patrně byl proti judikování proti výslovnému znění zákona. Jak ukázaly následné debaty zejména $\mathrm{v}$ anglosaské právní vědě, situace je však složitější, nebot' v otázkách, kdy soud představuje jediný orgán (pro izolovanou menšinu, parlamentní opozici anebo jednotlivce), je jeho zásah nezbytný.

Řešení uvedeného sporu spatřuji v tom, aby si soudy osvojili převážně pasivní roli, zejména rozhodují-li spory, které mohou být rovněž rozhodnuty demokratickou cestou, nebot’ pro ně neexistuje jednoznačné právní řešení podložené ústavou. Vedle toho je

83 KUMM, Mattias: Who is Afraid of the Total Constitution? Constitutional Rights as Principles and the Constitutionalization of Private Law. German Law Journal, č. 4/2006, s. 342-343.

84 SCHMITT, Carl: Der Hüter der Verfassung... Op. cit., s. 158.

85 Ibid, s. 155.

86 KELSEN, Hans: Wer soll der Hüter der Verfassung sein... Op. cit., s. 1565.

87 WINTR, Jan: Principy českého ústavního práva. 3. vyd., Plzeň: Aleš Čeněk, 2015, s. 95.

$88 \mathrm{~V}$ české literatuře se tématu vztahu ústavního soudnictví a politiky delší dobu věnuje J. Chmel. Srov. jeho př́spěvek CHMEL, Jan: Politika na ústavním soudě. Časopis pro právní vědu a praxi, 1. část: č. 2/2014, s. 178-185, 2. část: č. 4/2014, s. 475-483. BROZ, Jan - CHMEL, Jan: Pohled za oponu: Studie o vzniku Ústavy České republiky a o kontextu jeji interpretace. Praha: Leges, 2016, s. 66-117. Viz též BAŇOUCH, Hynek: Vztahy práva a politiky a jejich vliv na efektivnost práva. In SMEKAL, Hubert - POSPÍŠIL, Ivo (eds.): Soudcokracie nebo judicializace politiky: vztah práva a politiky (nejen) v časech krize. Brno: Masarykova Univerzita, 2013, s. 73-92.

89 Podle Marka Antoše se právě v této otázce liší moderní ústavní soudy nejvíce od kelsenovského modelu, a to proto, že jejich judikatura v oblasti základních práv se prakticky celá dotýká vágních a stručně formulovaných garancí práv, př́ípadně kolidujících veřejných zájmů, které ústavní soudce vedou často k hodnotovým soudům - viz ANTOŠ, Marek: Současné ústavní soudnictví... Op. cit., s. 41. 
praktické, aby si především ústavní soudy osvojily minimalistické rozhodování, které se orientuje na základní otázku ve sporu, přičemž ostatní související záležitosti ponechává nerozhodnuté. Tím se soud může vyvarovat možnosti chybných závěrů, plynoucích např́iklad z nedostatku informací, kterými nemusí při rozhodování disponovat, ale také kritiky z důvodu tvrzeného zasahování do pravomoci jiných, zejména demokraticky legitimovaných, orgánů státní moci.

JUDr. Pavel Ondřejek, Ph.D.

Univerzita Karlova, Právnická fakulta

ondrejek@prf.cuni.cz 